\title{
Lung Squamous Cell Carcinoma In Situ
}

National Cancer Institute

\section{Source}

National Cancer Institute. Lung Squamous Cell Carcinoma In Situ. NCI Thesaurus. Code C136719.

A preinvasive bronchial neoplastic lesion affecting the squamous epithelium. It is characterized by the absence of progression of maturation from base to luminal surface, basilar zone expansion with cellular crowding throughout the epithelium, absence of the intermediate zone, and surface flattening confined to the most superficial cells. The nuclear-to-cytoplasmic ratio is often high and variable, the chromatin is coarse and uneven, and mitotic figures are present through full thickness. The cell size may be markedly increased. Anisocytosis and pleomorphism may be present. (Adapted from WHO, 2015) 